eat fish twice a week at school ? Five trials, involving forty schools and 13,000 children, has indeed shown (see Fish in School Meals published by the authority) that children like fish as much as meat, provided it is of reasonable quality and attractively served. The surveys carried out by the authority and supported by evidence obtained by the Ministry of Technology's Torry Research Station also showed that fish is cheaper than meat and nutritionally just as good.

The authority now hopes to persuade the DES to revise its school meal recommendations, and the local education authorities to adopt purchase and handling specifications to control the quality of fish for schools.

\section{SCIENCE FAIR}

\section{World Series in School Science}

THE International Science Fair (ISF) programme is now in its twenty-first year and growing fast. Every year, more and more American students in the tenth, eleventh and twelfth grades at secondary schools answer its challenge to "try doing your own thing in science", which means finding a scientific project to study, either in or out of school, and exhibiting the results of their endeavours in the school science fair. From this beginning, the aspiring young scientist may find that his project has been selected for exhibition in one of 200 regional fairs, where it will be judged against strong competition for a place in the International Science Fair. Here, the 400 exhibitors will have the opportunity to win one of the many awards donated by more than thirty national scientific organizations and federal services, but, as Science Service, the non-profitmaking organization for the popularization of science which runs ISF, points out, the main award is the opportunity to gain a place in the final and to achieve the recognition among the scientific community which this brings. Consequently, every finalist receives an ISF Medal Award-"a rainbow ribboned silver medal with a gold science emblem".

The selection process for the ISF involves thousands of school fairs and millions of students, teachers, scientists, parents and visitors, and this certainly helps to popularize science in secondary schools. Moreover, the standard of the entries is usually very high, and sometimes they involve complex subjects; for example, last year's winners included projects on storing information in crystals, building synthetic peptides and an investigation into a possible relationship between mathematical formulae and marine mollusc growth. However, the International Science Fair is more like the "World Series" of science fairs, because its entrants are predominantly Americanout of forty-two major prizewinners last year, only one was not American-and it seems that the twenty-first International Science Fair, which will be held in Baltimore in May 1970, will follow a similar pattern.

\section{CHEMISTRY PRIZE}

\section{Conformation Analysis Honoured}

THIs year's Nobel Prize for Chemistry has gone to Professor Derek H. R. Barton at Imperial College, London, and Professor Odd Hassel, the distinguished Norwegian theoretical chemist, for their work "to develop and apply the concept of conformation in chemistry". The $£ 30,000$ award relates to the research done by Professor Hassel in the 1940s on the molecular structure of cyclohexane derivatives and Professor Barton's extension of the ideas of conformation to complex organic structures.

Dr Hassel uscd the techniques of electron diffraction, under what Professor Barton describes as incredibly difficult circumstances during the war, to make threedimensional images of simple molecules which he saw existed in preferred conformations. This helped him to realize that the analysis of the conformation of organic molecules could help to explain their chemical reactions and, in fact, could be used to predict the way they would react. Since then, conformation analysis has become a powerful tool in predicting the configuration of natural substances such as steroids, alkaloids and terpenes, in the analysis of reaction mechanisms and in the synthesis of organic molecules. One important application of this type of analysis is in drug research to find the part of a molecule at which combination with other substances takes place.

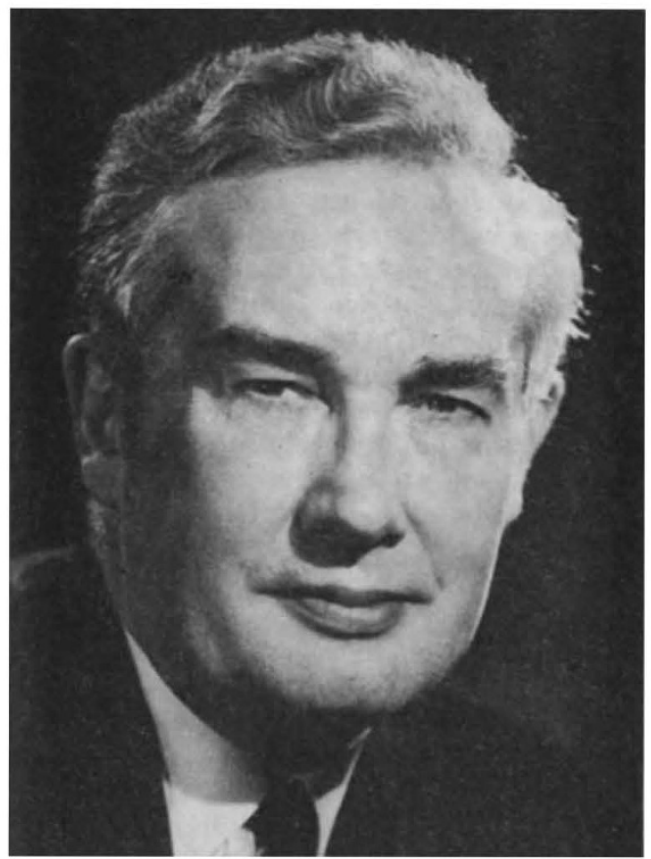

Since his original work on three-dimensional analysis, Professor Barton has gone on to study the paths by which natural substances are manufactured by plants and moulds. One of his chief interests now is the synthesis of biologically important steroid and alkaloid molecules.

Professor Hassel, who is 72, was a lecturer and later professor of physical chemistry at Oslo University from 1926 to 1964. Professor Barton, now 51, has been interested in steroid chemistry since he was a student at Imperial College. He followed up Hassel's work during a period when he was a visiting professor at Harvard, and he returned to Imperial College twelve years later as professor of organic chemistry.

\section{PHYSICS PRIZE}

\section{No Sirangeness Here}

The award of the Nobel Prize for Physics to Professor Murray Gell-Mann, the man who put forward the 